\title{
Quality and stability of eggs from laying hens fed with organic minerals and lycopene
}

\author{
Qualidade e estabilidade dos ovos de poedeiras \\ alimentadas com licopeno e minerais orgânicos
}

\begin{abstract}
Flavia Kleszez da Cruz ${ }^{I}$ Elis Regina de Moraes Garcia ${ }^{I^{*}}$ André Luiz Julien Ferraz Karina Márcia Ribeiro de Souza ${ }^{\text {II }}$ William Britez FelicianoIII Rosileide Vilalba Rohod
\end{abstract}

\section{ABSTRACT}

This study aimed to evaluate the effect of using lycopene and organic minerals in diets for laying hens on the egg quality and stability of eggs stored for 30 days under different storage environments. An entirely randomized design was adopted in $2 \times 3 \times 3$ factorial scheme (mineral sources $x$ lycopene levels $x$ storage periods) with six replicates of eight hens per experimental unit. The experimental diets were: feed containing inorganic minerals (IM) without added lycopene; IM with added lycopene (400mg $\mathrm{kg}^{-1}$ ); IM with added lycopene $(800 \mathrm{mg} \mathrm{kg}$ $\left.{ }^{1}\right)$; organic minerals $(O M)$ without added lycopene; OM with added lycopene (400mg $\mathrm{kg}^{-1}$ ); OM with added lycopene (800 $\mathrm{mg} \mathrm{kg}^{-1}$ ). After 112 days of feeding experimental diets, it was selected 60 eggs treatment ${ }^{1}$, which were later labeled, stored in room and refrigerated temperature, and subjected to different storage periods (0,15 and 30 days). Variables analyzed were: Haugh unit, yolk index, yolk color, albumen and yolk $p H$, and lipid oxidation (TBARS). Stability of eggs is not altered as a function of mineral sources and levels of lycopene studied. However, increasing storage time affects the quality of the eggs of laying hens at both storage conditions.

Key words: antioxidant, carotenoid, chelate, selenium, TBARS

\section{RESUMO}

Objetivou-se avaliar o efeito da utilização do licopeno e de minerais orgânicos em rações para poedeiras sobre a qualidade e estabilidade dos ovos armazenados por até 30 dias, em diferentes ambientes de conservação. Adotou-se um DIC em esquema fatorial $2 \times 3 \times 3$ (fontes de minerais $x$ niveis de licopeno $x$ periodos de armazenamento) com seis repetições $e$ oito aves por unidade experimental. As rações experimentais foram: ração contendo minerais inorgânicos (MI) sem a adição de licopeno; MI com a adição de licopeno (400mg $\mathrm{kg}^{-1}$ ); $\mathrm{MI}$ com a adição de licopeno (800 $\mathrm{mg} \mathrm{kg}^{-1}$ ); minerais orgânicos (MO) sem a adição de licopeno; $\mathrm{MO}$ com a adição de licopeno (400mg $\mathrm{kg}^{-1}$ ); $\mathrm{MO}$ com a adição de licopeno (800mg $\mathrm{kg}^{-1}$ ). Após 112 dias de fornecimento das rações experimentais, foram selecionados 60 ovos tratamento-1 que, posteriormente, foram identificados, acondicionados em temperatura ambiente e refrigerado, e submetidos a diferentes periodos de armazenamento (0, 15 e 30 dias). As variáveis analisadas foram: unidade Haugh, indice de gema, coloração de gema, $p H$ de albúmen e gema e oxidação lipídica (TBARS). A estabilidade dos ovos não é alterada em função das fontes minerais e dos níveis de licopeno estudados. No entanto, o aumento do periodo de estocagem prejudica a qualidade dos ovos de poedeiras semipesadas, em ambas as condições de armazenamento.

Palavras-chave: antioxidante, carotenoide, quelato, selênio, TBARS.

\section{INTRODUCTION}

Egg is considered one of the most complete foods in human nutrition, as its composition includes protein of excellent biological value, in addition to essential amino acids, vitamins, fatty acids and minerals (ALLEONI \& ANTUNES, 2001). Given that eggs have high levels of unsaturated fatty acids, which are more susceptible to lipid oxidation, studies have been carried out using antioxidants in bird diets, in order to preserve quality and increase shelf life considering that oxidative processes can deteriorate eggs during storage.

The antioxidant defense system is responsible for inhibiting and/or reducing the damages caused by the harmful action of free radicals and/or non-radical reactive species. Certain

\footnotetext{
IPrograma de Pós-graduação em Zootecnia, Universidade Estadual de Mato Grosso do Sul (UEMS), Unidade Universitária de Aquidauana, 79200-000, Aquidauana, MS, Brasil. E-mail: ermgarcia@uems.br. *Corresponding author.

IIFaculdade de Medicina Veterinária e Zootecnia, Universidade Federal de Mato Grosso do Sul (UFMS), Campo Grande, MS, Brasil.

${ }^{\text {IIIC }}$ Curso de Zootecnia, UEMS, Aquidauana, MS, Brasil.
} 
minerals, vitamins, carotenoids (beta-carotene, lycopene and lutein), bioflavonoids and tannins stand out within this system, and are considered nonenzyme defense components. Enzyme components include enzymes superoxide dismutase, glutathione peroxidase and catalase, which are classified as metalloenzymes, containing traces of minerals zinc, copper, selenium, manganese and iron, as cofactors (FERREIRA \& MATSUBARA, 1997; HALLIWELL \& GUTTERDGE, 1999).

Bird feeds formulas usually include minerals in inorganic form, which must first be solubilized upon reaching the GI tract to release ions and be absorbed. However, minerals in ionic form can undergo complexation with other diet components, hindering their absorption or becoming unavailable to animals. Given these uncertainties, the levels of minerals provided in diets are frequently higher than the minimums required to optimize performance, resulting in excess supply.

On the other hand, minerals added in inorganic form are absorbed by intestinal carriers of amino acids and peptides, and not by classic mineral carriers in the intestine, avoiding competition for the same absorption mechanisms. Therefore, not only is bioavailability greater, but organic minerals are promptly transported to the tissues, where they will remain stored for longer periods than inorganic materials (RUTZ et al., 2007).

As well as a pigment, lycopene is the carotenoid with the highest singlet oxygen capture capacity, possibly due to the presence of the two nonconjugated double bonds, making it more reactive (SHAMI \& MOREIRA, 2004). Nevertheless, its antioxidant role in layer diets is still poorly understood.

All of these antioxidants can act in conjunction with one another, forming an integrated antioxidant system. These interactions are vital for maximum protection against the harmful effects of free radicals and toxic products of cell metabolism, thus demonstrating that adding substances with antioxidant potential to bird diets - such as minerals and carotenoid substances - can further strengthen their antioxidant activity (SAHIN et al., 2006; SURAI, 2006; AJAKAIYE et al., 2011). Therefore, this research was developed with the objective of evaluating the effect of adding lycopene and organic minerals to layer feeds on the quality and stability of eggs stored for up to 30 days at different storage environments.

\section{MATERIAL AND METHODS}

The research was carried out at the Poultry Farming Sector of the Aquidauana University Unit and at the Animal Product Quality Laboratory of Universidade Estadual de Mato Grosso do Sul. A total of 288 Dekalb Brown laying hens (semi-heavy layers) were used, at 58 weeks of age, fed with the experimental feeds for a period of 112 days.

The experimental feeds (Table 1) were formulated to meet the nutritional needs of the lineage and the chemical composition of the diets according to the Dekalb Brown Management Guide (GRANJA PLANALTO, 2009) and ROSTAGNO et al. (2005). They were arranged as follows: IM without added lycopene; IM with added lycopene (400 $\left.\mathrm{mg} \mathrm{kg}^{-1}\right)$; IM with added lycopene $\left(800 \mathrm{mg} \mathrm{kg}^{-1}\right)$; $\mathrm{OM}$ without added lycopene; OM with added lycopene $\left(400 \mathrm{mg} \mathrm{kg}^{-1}\right)$; OM with added lycopene $\left(800 \mathrm{mg} \mathrm{kg}^{-1}\right)$.

The minerals used in organic form were: copper $(\mathrm{Cu})$, iron $(\mathrm{Fe})$, manganese $(\mathrm{Mn})$, zinc $(\mathrm{Zn})$ (metal - amino acid complex) and selenium (Se) (selenium yeast). Inclusion levels differed for the different sources of minerals (inorganic and organic), seeking in both cases to meet all mineral needs. An entirely randomized design was adopted, in a $2 \times 3 \times 3$ factorial scheme (sources of minerals $x$ lycopene levels $\mathrm{x}$ storage periods) with six replicates and eight birds per experimental unit.

After 112 days administering the experimental feeds, 60 eggs were selected from each treatment, based on the absence of cracks, blemishes or stains on the shell. These eggs were then labeled, placed in a cardboard tray, stored at different storage environments (room temperature: $30.05^{\circ} \mathrm{C}$ and $63.03 \%$ $\mathrm{RH}$; chilled temperature: $6.18^{\circ} \mathrm{C}$ and $\left.41.28 \% \mathrm{RH}\right)$ and subjected to different storage periods $(0,15$ and 30 days), comprising the 30-day experimental period.

Ten eggs per treatment were selected for each storage period and storage environment, to evaluate internal quality using the variables Haugh unit (HU), yolk index (YI), yolk color (YC), albumen $\mathrm{pH}(\mathrm{apH})$ and yolk $(\mathrm{ypH})$ and to measure lipid oxidation (TBARS method), by adapting the methodology described by RAMANATHAN \& DAS (1992) and VYNCKE (1970).

To evaluate internal quality, the chosen eggs were weighed individually on a semi-analytical balance $( \pm 0.001 \mathrm{~g})$ and then broken over a flat surface and smooth glass surface. Using a digital caliper, albumen and yolk height were determined and expressed in millimeters $(\mathrm{mm})$. Using the measurements of albumen height ( $\mathrm{mm}$ ) and egg unit weight (g), HU values were calculated as given by the equation described by SILVERSIDES \& BUDGELL (2004): $\mathrm{HU}=100 \log \left(\mathrm{H}+7.75-1.7 \mathrm{~W}^{0.37}\right)$, in which $\mathrm{H}$ $=$ albumen height $(\mathrm{mm})$ and $\mathrm{W}=$ egg weight $(\mathrm{g})$. 
Table 1 - Percentage and calculated compositions of the experimental feeds.

\begin{tabular}{|c|c|c|c|c|c|c|}
\hline Ingredients & IM & $\begin{array}{l}\mathrm{IM}+\mathrm{Lyc} \\
\left(400 \mathrm{mg} \mathrm{kg}^{-1}\right)\end{array}$ & $\begin{array}{l}\mathrm{IM}+\mathrm{Lyc} \\
\left(800 \mathrm{mg} \mathrm{kg}^{-1}\right)\end{array}$ & $\mathrm{OM}$ & $\begin{array}{l}\mathrm{OM}+\mathrm{Lyc} \\
\left(400 \mathrm{mg} \mathrm{kg}^{-1}\right)\end{array}$ & $\begin{array}{l}\mathrm{OM}+\mathrm{Lyc} \\
\left(800 \mathrm{mg} \mathrm{kg}^{-1}\right)\end{array}$ \\
\hline Corn, grain & 61.49 & 61.49 & 61.49 & 61.49 & 61.49 & 61.49 \\
\hline Soybean meal, $45 \%$ & 25.27 & 25.27 & 25.27 & 25.27 & 25.27 & 25.27 \\
\hline Soybean oil & 1.25 & 1.25 & 1.25 & 1.25 & 1.25 & 1.25 \\
\hline Limestone & 8.27 & 8.27 & 8.27 & 8.27 & 8.27 & 8.27 \\
\hline Dicalcium phosphate & 2.08 & 2.08 & 2.08 & 2.08 & 2.08 & 2.08 \\
\hline L-lysine $\mathrm{HCl}$ & 0.11 & 0.11 & 0.11 & 0.11 & 0.11 & 0.11 \\
\hline DL-methionine & 0.17 & 0.17 & 0.17 & 0.17 & 0.17 & 0.17 \\
\hline Sodium chloride & 0.35 & 0.35 & 0.35 & 0.35 & 0.35 & 0.35 \\
\hline Mineral and vitamin supplement ${ }^{*}$ & 0.10 & 0.10 & 0.10 & 0.30 & 0.30 & 0.30 \\
\hline Inert & 0.90 & 0.60 & 0.20 & 0.70 & 0.40 & 0.00 \\
\hline Lycopene ${ }^{* *}$ & 0.00 & 0.30 & 0.70 & 0.00 & 0.30 & 0.70 \\
\hline BHT & 0.01 & 0.01 & 0.01 & 0.01 & 0.01 & 0.01 \\
\hline Total & 100.00 & 100.00 & 100.00 & 100.00 & 100.00 & 100.00 \\
\hline $\operatorname{ME}\left(\mathrm{kcal} \mathrm{kg}^{-1}\right)$ & 2,800 & 2,800 & $\begin{array}{r}\text { d values----- } \\
2,800\end{array}$ & 2,800 & 2,800 & 2,800 \\
\hline $\mathrm{CP}(\%)$ & 17.0 & 17.0 & 17.0 & 17.0 & 17.0 & 17.0 \\
\hline Digestible methionine + cystine $(\%)$ & 0.65 & 0.65 & 0.65 & 0.65 & 0.65 & 0.65 \\
\hline Digestible lysine (\%) & 0.85 & 0.85 & 0.85 & 0.85 & 0.85 & 0.85 \\
\hline Calcium (\%) & 4.10 & 4.10 & 4.10 & 4.10 & 4.10 & 4.10 \\
\hline Available phosphorus (\%) & 0.48 & 0.48 & 0.48 & 0.48 & 0.48 & 0.48 \\
\hline Linoleic acid (\%) & 1.79 & 1.79 & 1.79 & 1.79 & 1.79 & 1.79 \\
\hline
\end{tabular}

IM: inorganic mineral (composition: $\mathrm{Cu}, 25 \%$; Fe, 28\%; Mn, 31\%; Se, 45\%; Zn, 35\%); OM: organic mineral (composition: $\mathrm{Cu}, 10 \%$; Fe, 6\%; Mn, 8\%; Se, 0.2\%; Zn, 10\%); Lyc: lycopene; 'Composition per kg of feed: Vitamin A, 7,000IU; Vitamin D3, 1,600IU; Vitamin E, 8IU; Vitamin K3, 1.0mg; Nicotinic acid, 20mg; Pantothenic acid, 7mg; Vitamin B , 1.0mg; Vitamin B B2, 0.010mg; Biotin, 0.02mg; Cu, 10mg; Fe; 50mg; I, 0.83mg; Mn, 65mg; Se, 0.30mg; Zn, 60mg; ${ }^{* *}$ Commercial product based on pure lycopene and tomato powder to provide 400 and $800 \mathrm{mg}$ of lycopene $\mathrm{kg}^{-1}$ of feed.

Next, yolk was measured using a manual caliper $( \pm 0.05 \mathrm{~mm})$ and YI (height/diameter) was calculated based on the mean values obtained. YC was analyzed using a DSM Yolk Color Fan ${ }^{\circledR}$. Next, $\mathrm{apH}$ and $\mathrm{ypH}$ were determined using a bench top $\mathrm{pH}$ meter (HANNA Instruments ${ }^{\circledR}$ ). For each storage environment, data were subjected to analysis of variance, Tukey's test was applied to compare the means $(\mathrm{P}<0.05)$.

\section{RESULTS AND DISCUSSION}

For eggs stored at room temperature there was an interaction $(\mathrm{P}<0.05)$ between mineral source and storage period for YC (Table 2). The unfolding of the interaction (Table 3) showed that the addition of an organic mineral source intensified the YC of fresh eggs when compared to the inorganic source. The initial effect possibly resulted in lower $\mathrm{YC}$ as the egg stocking period progressed only for this treatment. No isolated effect was observed $(\mathrm{P}>0.05)$ at the different sources of minerals and lycopene levels over the studied variables (Table 2).

TBARS values increased $(\mathrm{P}<0.05)$ as the stocking period for eggs at room temperature progressed, in agreement with those found by GIAMPIETRO et al. (2008), who observed that the lipid oxidation of egg yolks became more expressive when they were stored for 7, 14 and 21 days.

HU and YI values decreased as the storage period advanced $(\mathrm{P}<0.01)$, which may be explained by the countless chemical reactions that occur in the egg due to stocking time, especially at high temperatures. The main reaction is the degradation of the protein present in thick albumen, making it more liquid and consequently reducing its height.

With albumen protein degradation, there is excess water in the yolk, raising its percentage and making it more flat. Consequently, the yolk index is decreased, considering it is measured 
Table 2 - Values of TBARS, Haugh unit (HU), yolk index (YI), yolk color (YC), pH of albumen and egg yolks from semi-heavy layers fec different mineral sources (MS) and lycopene levels (LL) stored at room temperature for various storage periods (SP) (mean \pm standard error).

\begin{tabular}{|c|c|c|c|c|c|c|}
\hline \multirow{2}{*}{ Parameters } & \multirow{2}{*}{ TBARS (mg malonaldehyde $\mathrm{kg}^{-1}$ ) } & \multirow{2}{*}{$\mathrm{HU}$} & \multirow{2}{*}{$\mathrm{YI}(\mathrm{mm})$} & \multirow{2}{*}{$\mathrm{YC}$} & \multicolumn{2}{|c|}{-pH-----.--.-- } \\
\hline & & & & & Albumen & Yolk \\
\hline Inorganic & $0.287 \pm 0.02$ & $58.88 \pm 1.98$ & $0.27 \pm 0.01$ & $6.78 \pm 0.12$ & $8.89 \pm 0.04$ & $6.58 \pm 0.04$ \\
\hline Organic & $0.319 \pm 0.02$ & $57.95 \pm 1.03$ & $0.27 \pm 0.01$ & $7.02 \pm 0.12$ & $8.92 \pm 0.04$ & $6.58 \pm 0.04$ \\
\hline $0 \mathrm{mg} \mathrm{kg}^{-1}$ & $0.300 \pm 0.02$ & $58.73 \pm 2.36$ & $0.27 \pm 0.01$ & $6.77 \pm 0.15$ & $8.88 \pm 0.05$ & $6.63 \pm 0.05$ \\
\hline $400 \mathrm{mg} \mathrm{kg}^{-1}$ & $0.310 \pm 0.02$ & $56.19 \pm 2.41$ & $0.26 \pm 0.01$ & $6.97 \pm 0.15$ & $8.94 \pm 0.05$ & $6.59 \pm 0.05$ \\
\hline $800 \mathrm{mg} \mathrm{kg}^{-1}$ & $0.299 \pm 0.02$ & $60.33 \pm 2.41$ & $0.27 \pm 0.01$ & $6.98 \pm 0.15$ & $8.90 \pm 0.05$ & $6.51 \pm 0.05$ \\
\hline 0 days & $0.244^{\mathrm{b}} \pm 0.03$ & $92.13^{\mathrm{a}} \pm 2.54$ & $0.42^{\mathrm{a}} \pm 0.01$ & $7.21^{\mathrm{a}} \pm 0.16$ & $7.89^{c} \pm 0.05$ & $6.21^{\mathrm{c}} \pm 0.06$ \\
\hline 15 days & $0.313^{\mathrm{ab}} \pm 0.02$ & $49.14^{\mathrm{b}} \pm 2.27$ & $0.24^{\mathrm{b}} \pm 0.01$ & $7.00^{\mathrm{a}} \pm 0.14$ & $9.56^{\mathrm{a}} \pm 0.05$ & $6.59^{\mathrm{b}} \pm 0.05$ \\
\hline 30 days & $0.352^{\mathrm{a}} \pm 0.02$ & $33.98^{\mathrm{c}} \pm 2.36$ & $0.14^{\mathrm{c}} \pm 0.01$ & $6.50^{\mathrm{b}} \pm 0.14$ & $9.26^{\mathrm{b}} \pm 0.05$ & $6.93^{\mathrm{a}} \pm 0.05$ \\
\hline MS & 0.2604 & 0.7173 & 0.7885 & 0.1695 & 0.4951 & 0.9854 \\
\hline LL & 0.9355 & 0.4803 & 0.3646 & 0.5373 & 0.6800 & 0.2655 \\
\hline SP & 0.0208 & $<0.0001$ & $<0.0001$ & 0.0041 & $<0.0001$ & $<0.0001$ \\
\hline MS x LL & 0.1061 & 0.8150 & 0.4998 & 0.4248 & 0.7075 & 0.1450 \\
\hline MS x SP & 0.4013 & 0.6672 & 0.7158 & 0.0180 & 0.9108 & 0.2835 \\
\hline LL x SP & 0.2283 & 0.2106 & 0.5959 & 0.4385 & 0.5862 & 0.3765 \\
\hline MS x LL x SP & 0.9802 & 0.5925 & 0.9495 & 0.8618 & 0.7769 & 0.9542 \\
\hline
\end{tabular}

${ }^{\text {a}}$ Values with different superscripts in the same columns are statistically different by Tukey's test $(\mathrm{P}<0.05)$.

by the ratio between height and diameter of the yolk. These data corroborate those reported by BARBOSA et al. (2008), XAVIER et al. (2008) e GARCIA et al. (2010).

With regard to apH $(\mathrm{P}<0.01)$, the highest values were observed at 15 days of storage. This result is possibly related to the dissociation of carbonic acid that is converted into water and the diffusion of $\mathrm{CO}_{2}$ through the shell into the environment, thus reducing acidity, as it is one of the components of the buffer system of albumen. The ypH $(\mathrm{P}<0.01)$ showed the lowest values with 30

Table 3 - Unfolding of the interaction between mineral sources and storage periods for yolk color (YC).

\begin{tabular}{lccc}
\hline \multirow{2}{*}{ Mineral source } & \multicolumn{3}{c}{------Storage period (days)------------ } \\
& \multicolumn{1}{c}{0} & \multicolumn{1}{c}{15} & \multicolumn{1}{c}{30} \\
\hline Inorganic & $6.75 \pm 0.16^{\mathrm{b}}$ & $6.95 \pm 0.25$ & $6.67 \pm 1.17$ \\
Organic & $7.67 \pm 0.17^{\mathrm{Aa}}$ & $7.07 \pm 0.55^{\mathrm{B}}$ & $6.33 \pm 0.19^{\mathrm{C}}$ \\
\hline
\end{tabular}

Means followed by lowercase letters in the columns, and means followed by uppercase letters in the rows, differ by Tukey's test $(\mathrm{P}<0.05)$. days of storage, in agreement with those reported by SINGH \& PANDA (1990).

An interaction was observed $(\mathrm{P}<0.05)$ for the eggs stored under refrigeration between lycopene levels and storage periods for $\mathrm{YC}$ and $\mathrm{ypH}$ (Table 4). With the unfolding of the interaction (Table 5), it was observed that using $800 \mathrm{mg}$ of lycopene $\mathrm{kg}^{-1}$ of feed stabilized the intensity of YC as the stocking period progressed.

Bioavailability of lycopene is related to its isomeric forms. When ingested in its natural form (trans-lycopene), lycopene is poorly absorbed. Nevertheless, studies have shown that the thermal processing of tomatoes and its products - rich sources of lycopene - improve bioavailability, so that it breaks the cell wall and allows the extraction of lycopene from the chromoplasts (WILLCOX et al., 2003).

Due to its highly conjugated structure, lycopene is subject to oxidative degradation and cis-trans isomerism, the latter which is induced by light, temperature or chemical reactions. However, the results indicated that cooling the eggs preserved the lycopene structure, in that the rate of $800 \mathrm{mg} / \mathrm{kg}$ was able to stabilize yolk color intensity - that is, 
Table 4 - Values of TBARS, Haugh unit (HU), yolk index (YI), yolk color (YC), pH of albumen and egg yolks from semi-heavy layers fed different mineral sources (MS) and lycopene levels (LL) stored under refrigeration for various storage periods (SP) (mean \pm standard error).

\begin{tabular}{|c|c|c|c|c|c|c|}
\hline \multirow{2}{*}{ Parameters } & \multirow{2}{*}{ TBARS (mg malonaldehyde $\mathrm{kg}^{-1}$ ) } & \multirow{2}{*}{$\mathrm{HU}$} & \multirow{2}{*}{ YI (mm) } & \multirow{2}{*}{$\mathrm{YC}$} & \multicolumn{2}{|c|}{-pH------------' } \\
\hline & & & & & Albumen & Yolk \\
\hline ------------------ & & $-x-x-3$ & -1 - & ---------------- & & \\
\hline Inorganic & $0.266 \pm 0.02$ & $87.04 \pm 1.37$ & $0.43 \pm 0.00$ & $7.10^{\mathrm{b}} \pm 0.13$ & $8.79 \pm 0.03$ & $6.39^{\mathrm{b}} \pm 0.03$ \\
\hline Organic & $0.276 \pm 0.02$ & $86.03 \pm 1.37$ & $0.44 \pm 0.00$ & $7.51^{\mathrm{a}} \pm 0.13$ & $8.78 \pm 0.03$ & $6.47^{\mathrm{a}} \pm 0.03$ \\
\hline \multicolumn{7}{|l|}{ LL } \\
\hline $0 \mathrm{mg} \mathrm{kg}^{-1}$ & $0.287 \pm 0.02$ & $85.24 \pm 1.68$ & $0.43^{\mathrm{b}} \pm 0.00$ & $7.11^{\mathrm{b}} \pm 0.15$ & $8.75^{\mathrm{b}} \pm 0.04$ & $6.40^{\mathrm{b}} \pm 0.03$ \\
\hline $400 \mathrm{mg} \mathrm{kg}^{-1}$ & $0.259 \pm 0.02$ & $85.03 \pm 1.68$ & $0.43^{\mathrm{b}} \pm 0.00$ & $7.17^{\mathrm{b}} \pm 0.15$ & $8.87^{\mathrm{a}} \pm 0.04$ & $6.51^{\mathrm{a}} \pm 0.03$ \\
\hline $800 \mathrm{mg} \mathrm{kg}^{-1}$ & $0.268 \pm 0.02$ & $89.34 \pm 1.68$ & $0.45^{\mathrm{a}} \pm 0.00$ & $7.63^{\mathrm{a}} \pm 0.15$ & $8.74^{\mathrm{b}} \pm 0.04$ & $6.40^{\mathrm{b}} \pm 0.03$ \\
\hline 0 days & $0.244 \pm 0.02$ & $92.69^{\mathrm{a}} \pm 1.81$ & $0.43 \pm 0.01$ & $7.21 \pm 0.17$ & $7.95^{\mathrm{c}} \pm 0.04$ & $6.21^{\mathrm{c}} \pm 0.03$ \\
\hline 15 days & $0.301 \pm 0.02$ & $85.01^{\mathrm{b}} \pm 1.62$ & $0.43 \pm 0.00$ & $7.27 \pm 0.15$ & $9.27^{\mathrm{a}} \pm 0.04$ & $6.47^{\mathrm{b}} \pm 0.03$ \\
\hline 30 days & $0.269 \pm 0.02$ & $81.90^{\mathrm{b}} \pm 1.62$ & $0.44 \pm 0.00$ & $7.43 \pm 0.15$ & $9.14^{\mathrm{b}} \pm 0.04$ & $6.62^{\mathrm{a}} \pm 0.03$ \\
\hline MS & 0.6572 & 0.6016 & 0.2522 & 0.0283 & 0.7766 & 0.0325 \\
\hline LL & 0.5832 & 0.1262 & 0.0042 & 0.0402 & 0.0475 & 0.0140 \\
\hline SP & 0.1160 & 0.0001 & 0.2183 & 0.5741 & $<0.0001$ & $<0.0001$ \\
\hline MS x LL & 0.3729 & 0.6014 & 0.7789 & 0.9075 & 0.9299 & 0.1872 \\
\hline MS x SP & 0.8323 & 0.0824 & 0.0488 & 0.0613 & 0.8155 & 0.2765 \\
\hline LL x SP & 0.4363 & 0.4310 & 0.6796 & 0.0284 & 0.2111 & 0.0298 \\
\hline MS x LL x SP & 0.6131 & 0.2272 & 0.1197 & 0.6851 & 0.9794 & 0.2782 \\
\hline
\end{tabular}

${ }^{a}$ Values with different superscripts in the same row are statistically different by Tukey's test $(\mathrm{P}<0.05)$.

maintain its pigment activity during the stocking period of the eggs.

For the ypH variable, the unfolding of the interaction between lycopene levels and the storage period (Table 5) demonstrated an increase in values as stocking time advanced, regardless of the lycopene levels studied. According to SHANG

Table 5 - Unfolding of the interactions between lycopene levels and storage periods yolk color (YC) and $\mathrm{pH}(\mathrm{ypH})$

\begin{tabular}{|c|c|c|c|}
\hline \multirow{2}{*}{$\begin{array}{l}\text { Lycopene levels } \\
\left(\mathrm{mg} \mathrm{kg}^{-1}\right)\end{array}$} & \multicolumn{3}{|c|}{---------------Storage period (days)------------' } \\
\hline & 0 & 15 & 30 \\
\hline 0 & $7.13 \pm 0.26$ & $7.20 \pm 0.25^{\mathrm{ab}}$ & $7.00 \pm 0.15^{\mathrm{b}}$ \\
\hline 400 & $7.50 \pm 0.24^{\mathrm{A}}$ & $6.70 \pm 0.33^{\mathrm{Bb}}$ & $7.30 \pm 0.21^{\mathrm{Ab}}$ \\
\hline 800 & $7.00 \pm 0.29^{\mathrm{B}}$ & $7.90 \pm 0.31^{\mathrm{ABa}}$ & $8.00 \pm 0.30^{\mathrm{Aa}}$ \\
\hline 0 & $6.18 \pm 0.03^{\mathrm{Cab}}$ & $6.39 \pm 0.06^{\mathrm{Bb}}$ & $6.62 \pm 0.06^{\mathrm{Aab}}$ \\
\hline 400 & $6.32 \pm 0.06^{\mathrm{Ba}}$ & $6.47 \pm 0.07^{\mathrm{Bb}}$ & $6.73 \pm 0.03^{\mathrm{Aa}}$ \\
\hline 800 & $6.14 \pm 0.04^{\mathrm{Cb}}$ & $6.55 \pm 0.05^{\mathrm{Aa}}$ & $6.52 \pm 0.06^{\mathrm{Bb}}$ \\
\hline
\end{tabular}

Means followed by lowercase letters in the columns, and means followed by uppercase letters in the rows, differ by Tukey's test $(\mathrm{P}<0.05)$. et al. (2004), during storage there is an exchange of ions from the albumen with hydrogen ions in the yolk, causing ypH to increase.

No isolated effect $(\mathrm{P}>0.05)$ of the sources of minerals was observed on the studied variables for eggs stored at chilled temperature. With regard to lycopene levels, the highest values for $\mathrm{YI}(\mathrm{P}<0.01)$ and apH $(\mathrm{P}<0.05)$ were observed with the use of $800 \mathrm{mg}$ and $400 \mathrm{mg}$ of lycopene $\mathrm{kg}^{-1}$ of feed, respectively. The values of TBARS and YI remained stable $(\mathrm{P}>0.05)$ during the stocking period under refrigeration, showing that storage under lower temperatures minimized quality losses and egg stability.

$\mathrm{HU}$ values of the eggs decreased $(\mathrm{P}<0.01)$ with 15 - and 30-day storage when compared to fresh eggs. Similar results were found by ALLEONI \& ANTUNES (2001), BARBOSA et al. (2008) and GARCIA et al. (2010). The highest values for the variables apH $(\mathrm{P}<0.01)$ were obtained with 15 and 30 days, respectively.

\section{CONCLUSION}

Egg stability is not altered as a result of the mineral sources (organic and inorganic) or lycopene levels (400 and 800mg) studied herein. Nevertheless, 
longer stocking periods hinder the quality of eggs from semi-heavy layers, under both storage conditions.

\section{BIOETHICS AND BIOSSECURITY COMMITTEE APPROVAL}

This project was approved by the ETHICS COMMITTEE ON ANIMAL USE/UEMS, sob protocol no. 018/2013, on August 14, 2013.

\section{ACKNOWLEDGEMENTS}

The authors aknowledge the Conselho Nacional de Desenvolvimento Científico e Tecnológico (CNPq) for the fellowship award (Process number 480100/2011-0) and Coordenação de Aperfeiçoamento de Pessoal de Nível Superior (CAPES) for the scholarship.

\section{REFERENCES}

AJAKAIYE, J.J. et al. Vitamins $\mathrm{C}$ and $\mathrm{E}$ can alleviate adverse effects of heat stress on live weight and some egg quality profiles of layer hens. Pakistan Veterinary Journal, v.31, p.45-49, 2011. Available from: <http://www.pvj.com.pk/pdf-files/31_1/45-49. pdf>. Accessed: Oct. 19, 2012.

ALLEONI, A.C.C.; ANTUNES, A.J. Haugh unit as a measure of the quality of heneggs stored under refrigeration. Scientia Agricola, v.58, p.681-685, 2001. Available from: <http://dx.doi. org/10.1590/S0103-90162001000400005>. Accessed: Oct. 19, 2012. doi: 10.1590/S0103-90162001000400005.

BARBOSA, N.A.A. et al. Quality of eggs from commercial layers stored for different times and environment conditions. ARS Veterinaria, v.24, p.127-133, 2008. Available from: <http://dx.doi. org/10.15361/2175-0106.2008v24n2p127-133>. Accessed: Oct. 19, 2012. doi: 10.15361/2175-0106.2008v24n2p127-133.

FERREIRA, A.L.; MATSUBARA, L.S. Free radicals: concepts, associated diseases, defense system and oxidative stress. Revista da Associação Médica Brasileira, v.43, p.61-68, 1997. Available from: <http://dx.doi.org/10.1590/S0104-42301997000100014>. Accessed: Oct. 19,2012. doi: 10.1590/S0104-42301997000100014.

GARCIA, E.R.M. et al. Egg quality of lay hens stored at different temperature and storage conditions. Revista Brasileira de Saúde e Produção Animal, v.11, p.505-518, 2010. Available from: <http:// www.rbspa.ufba.br/index.php/rbspa/article/viewFile/1703/986>. Accessed: Oct. 19, 2012.

GIAMPIETRO, A. et al. Estudo da metodologia de TBARS em ovos. Departamento de Tecnologia - Unesp, 2008. Disponível em: $<$ http://www.avisite.com.br/cet/img/20080506_alinetbars.pdf $>$. Accessed: Oct. 19, 2012.

GRANJA PLANALTO. Manual de manejo das poedeiras Dekalb Brown. Uberlândia: Côrtes, 2009. 39p.

HALLIWELL, B.; GUTTERDGE, J.M.C. Free radical, other reactive species and disease. In: HALLIWELL, B.; GUTTERDGE,
J.M.C. Free radicals in biology and medicine. 3.ed. Oxford: Clarenton, 1999. p.617-783.

RAMANATHAN, L.; DAS, N.P. Studies on the control of lipid oxidation in ground fish by some polyphenolic natural products. Journal of Food Chemistry, v.40, p.17-21, 1992. Available from: $<$ http://pubs.acs.org/doi/pdf/10.1021/jf00013a004>. Accessed: Oct. 29, 2012. doi: 10.1021/jf00013a004.

ROSTAGNO, H.S. et al. Tabelas brasileiras para aves e suínos: composição de alimentos e exigências nutricionais. 2.ed. Viçosa: UFV, 2005. 186p.

SAHIN, K. et al. Effects of lycopene supplementation on antioxidant status, oxidative stress, performance and carcass characteristics in heat-stressed Japonese quail. Journal of Thermal Biology, v.31, p.307-312, 2006. Available from: <http://dx.doi.org/10.1016/j. jtherbio.2005.12.006>. Accessed: Oct. 29, 2012. doi: 10.1016/j. jtherbio.2005.12.006.

SHAMI, N.; MOREIRA, E. Lycopene as an antioxidant agent. Revista da Nutrição, v.17, p.227-36, 2004. Available from: <http:// dx.doi.org/10.1590/S1415-52732004000200009>. Accessed: Oct. 29, 2012. doi: 10.1590/S1415-52732004000200009.

SHANG, X.G. et al. Effects of dietary conjugated linoleic acid on the productivity of laying hens and egg quality during refrigerated storage. Poultry Science, v.83, p.1688-1695, 2004. Available from: < http://dx.doi.org/10.1093/ps/83.10.1688>. Accessed: Oct. 29, 2012. doi: $10.1093 / \mathrm{ps} / 83.10 .1688$.

SILVERSIDES, F.G.; BUDGELL, K. The relationships among measures of egg albumen height, $\mathrm{pH}$, and whipping volume. Poultry Science, v.83, p.1619-1623, 2004. Available from: $<$ http:// dx.doi.org/10.1093/ps/83.10.1619>. Accessed: Oct. 29, 2012. doi: $10.1093 / \mathrm{ps} / 83.10 .1619$.

SINGH, R.P.; PANDA, B. Comparative study on some quality attributes of quail and chicken eggs during storage. Indian Journal of Animal Sciences, v.60, p.114-117, 1990.

SURAI, P.F. Selenium in nutrition and health. United Kingdom: Nottingham University, 2006. 974p.

VYNCKE, B.W. Direct determination of the thiobarbituric acid value in trichloracetic acid extracts of fish as a measure of oxidative rancidity. Fette-Scifen Anstrichmittel, v.72, p.1084-1087, 1970. Available from: <http://onlinelibrary.wiley.com/doi/10.1002/ lipi.19700721218/pdf>. Accessed: Oct. 29, 2012. doi: 10.1002/ lipi.19700721218.

WILLCOX, J.K. et al. Tomatoes and cardiovascular health. Critical Reviews in Food Science and Nutrition, v.43, p.1-18, 2003. Available from: <http://dx.doi. org/10.1080/10408690390826437>. Accessed: Oct. 29, 2012. doi: $10.1080 / 10408690390826437$.

XAVIER, I.M.C. et al. Quality of consume eggs submitted to different storage conditions. Arquivo Brasileiro de Medicina Veterinária e Zootecnia, v.60, p.953-959, 2008. Available from: <http://dx.doi.org/10.1590/S010209352008000400026>. Accessed: Oct. 29, 2012. doi: 10.1590/ S0102-09352008000400026. 